\title{
Applied Landslide Geomorphology - some Examples from Slovenia
}

\author{
Matija Zorn, Blaž Komac
}

This article deals with landslide geomorphology, which should be placed alongside fluvial, tectonic, karst, coast, or slope geomorphology. Slovenia is used as an example to present landslide susceptibility mapping and the relative landslide rate, which was used to quantify the relative role of landslides in recent relief development in comparison to other fluvio-denudational or erosion processes. Landslides are a geographical constant in certain areas, and in the past some researchers have also used expressions such as landslideprone region for certain regions of Slovenia. The last section deals with geographers' role in landslide hazard research, which consists of several activities, although map-making remains the fundamental skill applied by geomorphologists. Methods of landslide hazard assessment are also discussed.

Key words: landslides, geomorphic processes, spatial planning, Slovenia

\section{Primijenjena geomorfologija klizišta - neki primjeri iz Slovenije}

Rad se bavi geomorfologijom klizišta, koja bi se trebala svrstati uz fluvijalnu, kršku, obalnu, padinsku ili strukturnu geomorfologiju. Slovenija je uzeta kao primjer kako bi se predstavilo kartiranje vjerojatnosti pojave klizišta i kako bi se odredio relativni udio procesa klizanja u ukupnom intenzitetu denudacije što zapravo služi pri kvantificiranju relativne uloge klizišta u recentnom razvoju reljefa u usporedbi s drugim fluviodenudacijskim i erozijskim procesima. Klizišta su geografska konstanta u određenim područjima te su u prošlosti za neke regije u Sloveniji upotrebljavani i termini poput regije podložne klizanju. Zadnji dio rada bavi se ulogom geografa u istraživanju rizika od klizišta, koja se sastoji od niza aktivnosti, no osnovna je vještina koju primjenjuju geomorfolozi i dalje izrada karata. Raspravlja se i o metodama procjene rizika od klizišta.

Ključne riječi: klizišta, geomorfološki procesi, prostorno planiranje, Slovenija 


\section{INTRODUCTION}

Are landslides an important factor in landform evolution? If the answer is yes, then landslide geomorphology should be placed alongside fluvial, tectonic, karst, coast or slope geomorphology. Current research on landslides is usually oriented towards specific phenomena or towards regional analysis; most often they do not apply to morphogenesis, which is typical for all other listed geomorphological areas. Crozier (2010) states that landslides have been recognized variously as hazardous phenomena, sources of sediment, transportation agents, and manifestations of land degradation and environmental change. Although they have been seen as significant hillslope processes capable of carrying out quanta of work, their role in governing the style and pace of landform evolution has been neglected until recently.

This paper uses the example of Slovenia to present landslide susceptibility mapping (Figs. 4 and 5) and the relative landslide rate (Fig. 2), which was used to quantify the relative role of landslides in recent relief development in comparison to other fluviodenudational or erosion processes. We found that the geomorphic role of landslides is relatively important, which has already been confirmed by other researchers (e.g. Glade and Crozier, 2010). This fact makes landslide geomorphology an important element in spatial planning; for example, in producing the municipal spatial plans that are required by law in many European countries.

According to Crozier $(1999,83)$, landslides are of interest to geographers for three main reasons:

- they represent an important geomorphic process;

- they are sensitive indicators of environmental change (e.g., they represent a shortterm adjustment to the disturbance of the natural system);

- they can present a serious natural hazard.

\section{APPLIED GEOMORPHOLOGY AND NATURAL HAZARDS}

"Geomorphologists are in a unique position to predict the type and amount of distortion that will occur when society chooses to alter natural landscape and processes" (Coates, 1984, 130). However, this latent ability is inadequate if it does not involve the application of existing knowledge. Alexander $(1991,57)$ sees three reasons for this: geomorphologists have been slow to create or utilize opportunities to apply their skills to problems in practice; geomorphology has retained something of the aura of a purely theoretical science; and, potential clients have not always perceived the need for landform studies before beginning development projects.

The application of geomorphology to engineering and environmental issues has been described in many works (for references see, e.g., Alexander, 1991; Montz and Tobin, 2011). Geomorphologists'work on natural hazards (Alexander, 1991, 58) has mainly concentrated on floods (e.g., floodplain delineation, flood deposit recognition and dating, and monitoring of changes in river channel positions and patterns), mass movements (landslide mapping, interpretation and prediction, and slope instability delineation), earthquakes (e.g., seismic 
landslide delineation and study of disruption caused to drainage networks), volcanoes (e.g., lahar, lava flow, deposits, dating of events, and erosion), and land degradation (e.g., studies of desertification and soil erosion).

\section{APPLICATION-ORIENTED LANDSLIDE RESEARCH}

"The ultimate goal in landslide hazard assessment is successful prediction of the place of occurrence of an event, its impact characteristics and relationship with time ... In other words, identifying the threat from landslide hazard means finding out what, where, when and how dangerous" they are (Crozier, 1999, 85).

According to Crozier $(1999,87)$, the geographers' role in landslide hazard research consists of:

- terrain analysis and geomorphological mapping to identify former landslide features;

- investigation of hazards through multiple sources; for example, historical records, urban development, climate records, geology, geomorphology, and hydrology; and,

- assessment of vulnerability, risk, and impacts through analysis of physicalgeographical and human-geographical factors.

Among geographers, geomorphologists in particular assist planners by providing information on the following (Alexander, 1991, 64; Glade 2005, 191; Zorn and Komac, 2006, 69):

- identification of geomorphic processes within the study area;

- determination of spatial distribution and level of activity of geomorphic processes;

- detailed characterization and categorization of geomorphic processes;

- explanation of relief forms or determining slope stability and identifying unstable relief forms;

- ascertaining past geomorphic processes, their scope, and when they occurred (return period or frequency of occurrence);

- assessment of the origin of sediments;

- defining regions where geomorphic processes may occur in the future;

- assessing the quantity of mobile material that geomorphic processes may carry to a lower location;

- modelling movement and defining sedimentation (accumulation) areas; and,

- calibrating models or comparing results of modelling with measurements and assessments of actual intensity of geomorphic processes.

The role of geomorphologists primarily lies, therefore, in identifying potentially dangerous areas and the geomorphic processes that take place in them.

"Geographers have been at the forefront of regional landslide hazard assessment employing techniques such as terrain analysis, geomorphic mapping and geographical information systems" (Crozier, 1999, 85). 
Hrvatski geografski glasnik 73/2 (2011.)
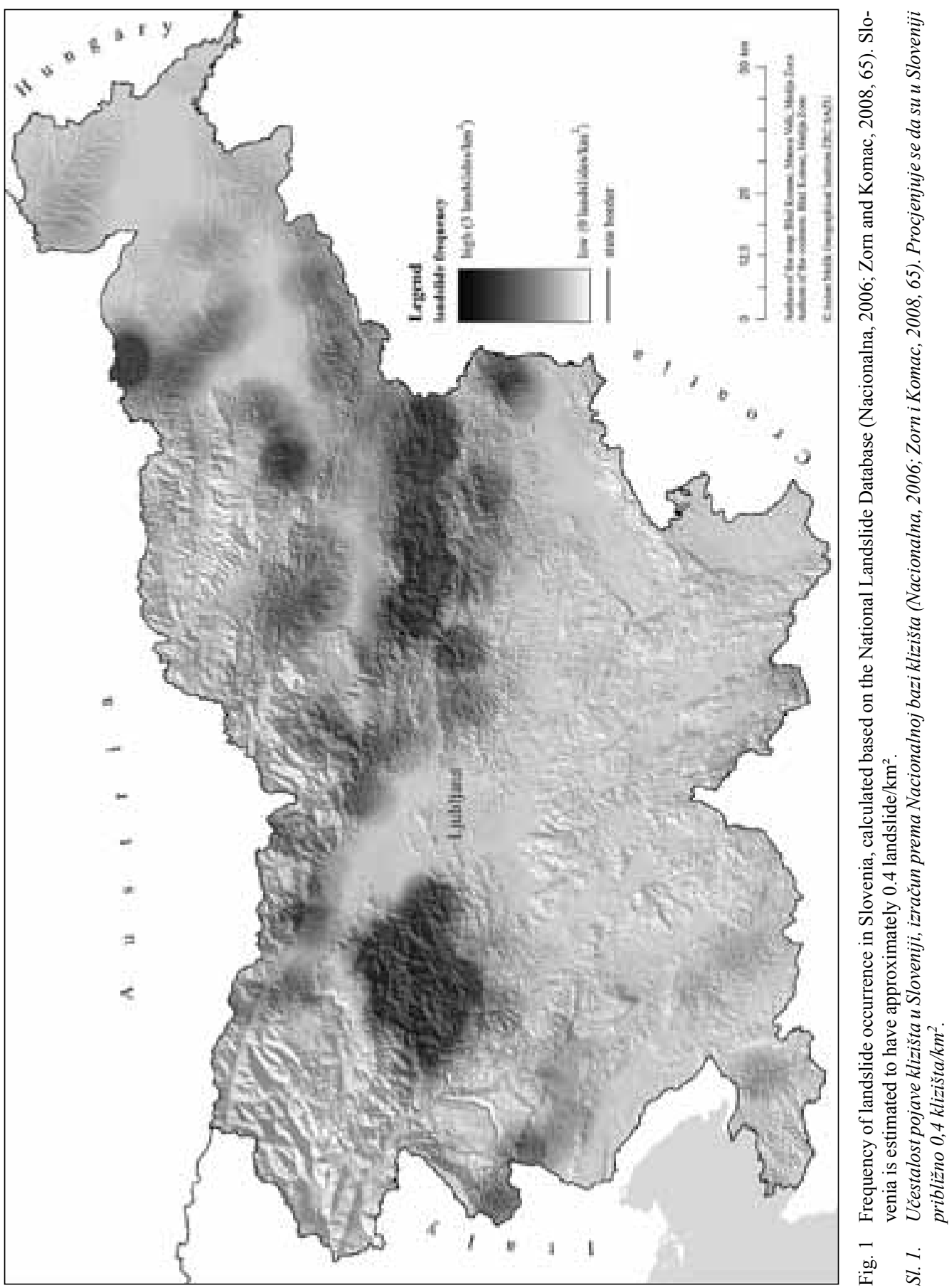

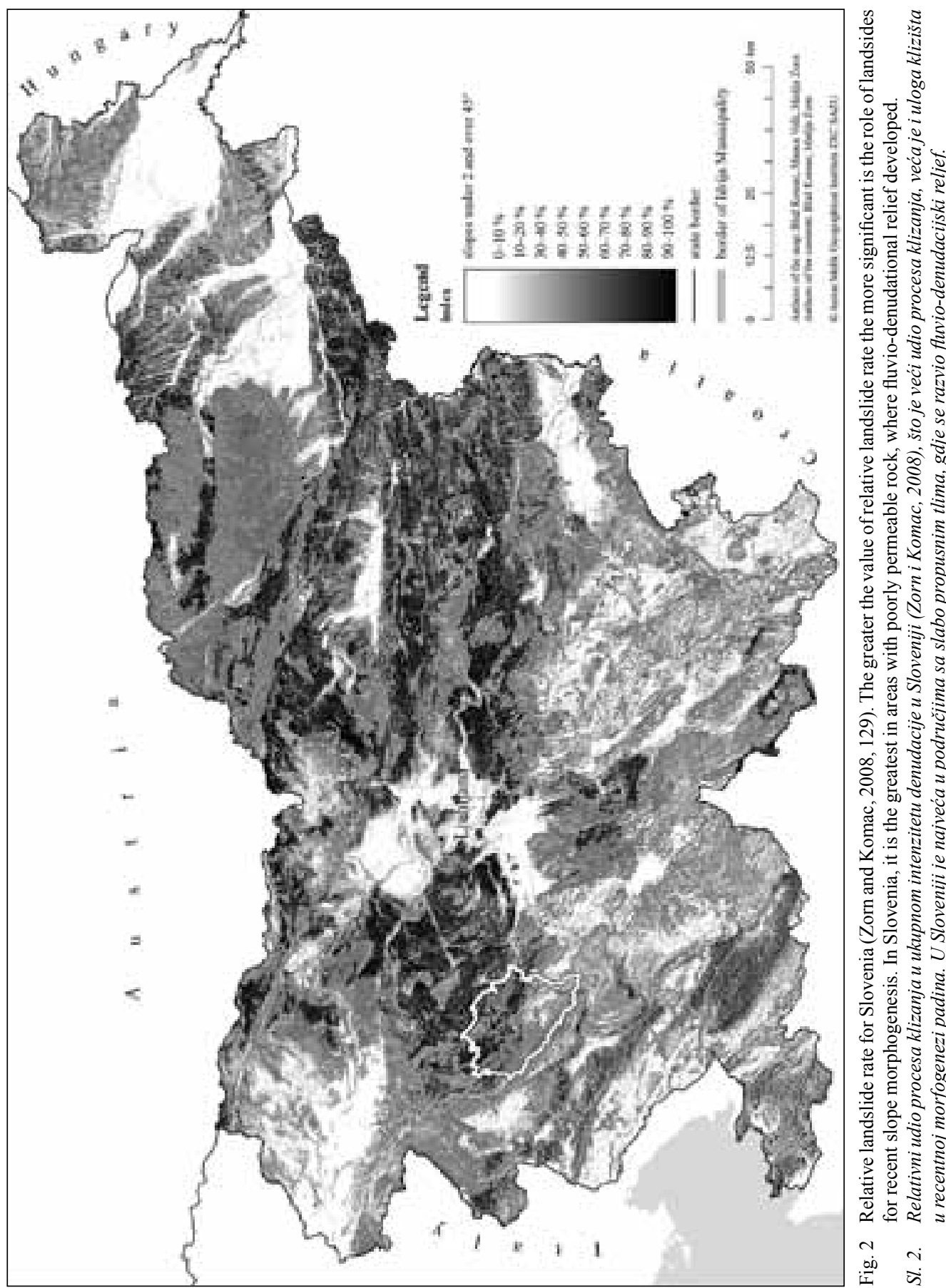


\section{LANDSLIDES AS A RECENT MORPHOGENETIC FACTOR}

Landslides are a geographical constant in certain areas, and some researchers in the past have also used expressions such as slippage- or landslide-prone region (Fig. 3) for certain regions of Slovenia (see sources in Zorn and Komac, 2011a). Nonetheless, spatial planning encounters difficulties in such areas because the principal recent geomorphic processes that shape them are still considered to be interfering factors rather than component parts of them.

With the help of the relative landslide rate (i.e. the ratio between the landslide mobilization rate and general denudation rate; Cendrero and Dramis, 1996, 197; Fig. 2), we sought to quantitatively define the significance of landslides in recent morphogenesis on the one hand, and on the other to raise awareness among the users of these spaces that landslides are a constant phenomenon in certain Slovenian areas.

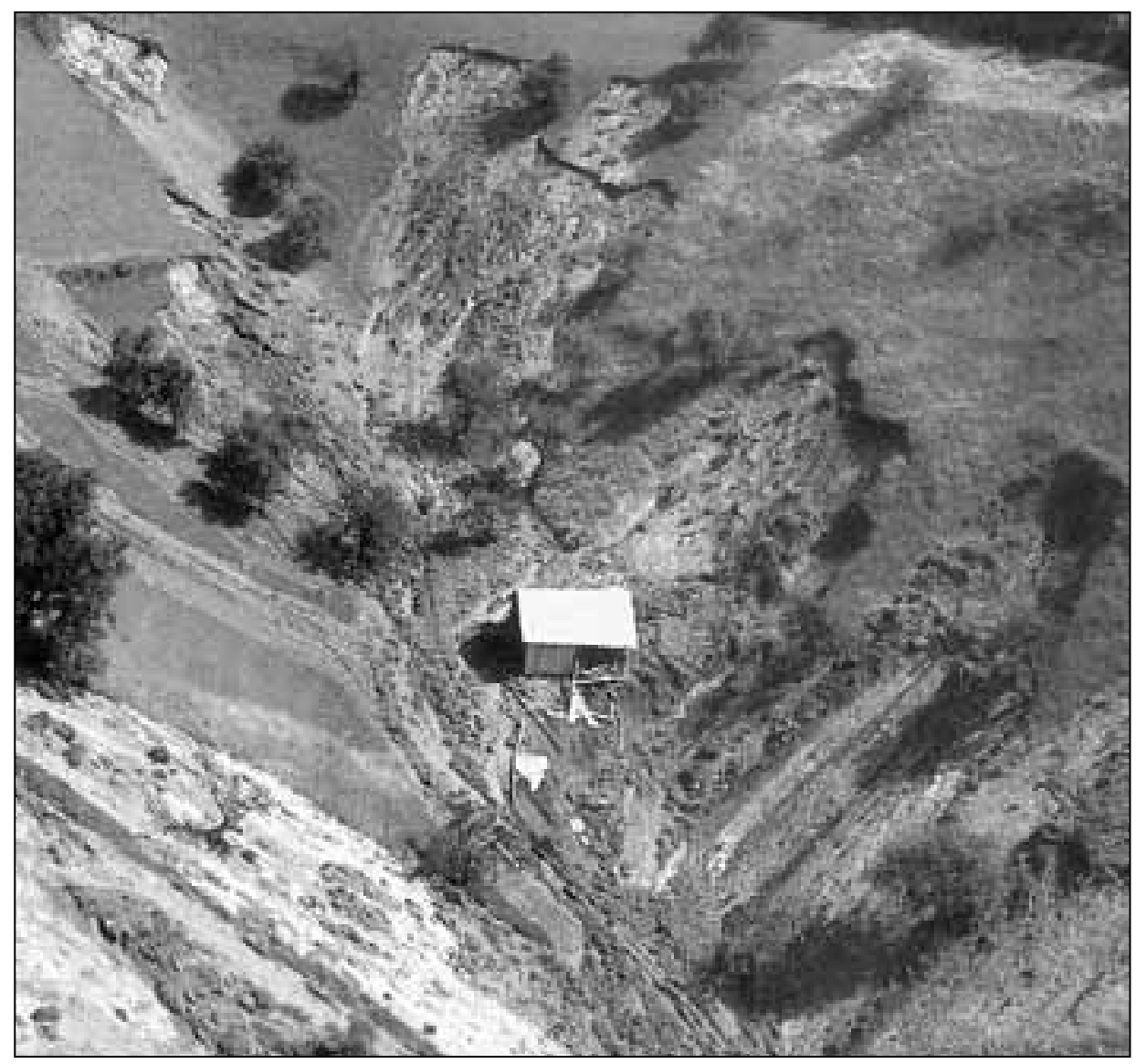

Fig. 3 The Haloze Hills in northeast Slovenia are a typical example of a "landslide-prone region" in Slovenia. After heavy precipitation in July 1989, several thousand slumps were triggered (photo: Milan Orožen Adamič).

Sl. 3. Područje Haloze u sjeveroistočnoj Sloveniji tipični je primjer ,, regije podložne klizanju”. Nakon velike količine padalina u srpnju 1989., opaženo je nekoliko tisuća klizišta (fotografija: Milan Orožen Adamič). 


\section{LANDSLIDE HAZARD ASSESSMENT}

Alexander $(1991,58)$ states that "the fundamental skill applied by the geomorphologist is still map-making". For example, creating landslide susceptibility maps is one of the basic methods of landslide prevention. In Slovenia we produce these with the help of a geographical information system, which includes digital elevation models (with $25 \times$ $25 \mathrm{~m}$ grid resolution for the national scale, $12.5 \times 12.5 \mathrm{~m}$ grid resolution for the regional scale, and more detailed grid resolution for the local scale), several physical geographical landscape elements, and the National Landslide Database.

Methods of landslide hazard assessment are divided into direct (qualitative or empirical) and indirect (quantitative) methods. The direct method most frequently used is (geomorphological) mapping. Its accuracy depends on the experience and expertise of cartographers, which is why the outcome demands a considerable amount of time to be completed; however, because of the fieldwork performed, they are more accurate (but also more expensive) than maps produced using indirect methods (van Westen et al., 1999). The cartographic results of various researchers may differ by 55 to $65 \%$ or even up to $80 \%$ (Ardizzone et al., 2002), which renders them extremely subjective.

Because one seeks to be as objective as possible in producing these kinds of maps, cheaper and faster indirect methods are often used. These are generally divided into deterministic, statistical, and probabilistic methods. Deterministic methods are characterized by subjectivity; in statistical methods, this is reduced by using statistics, whereas in probabilistic methods subjectivity is (almost) completely avoided (van Westen et al., 1999). We have already used all of these in Slovenia (e.g., Zorn and Komac, 2008; 2009; Ciglič et al., 2010), and in this article we have used a statistical method known as the certainty factor method to create a landslide susceptibility map for the entire territory of Slovenia (Fig. 4) and for a selected municipality (the Municipality of Idrija in western Slovenia; Fig. 5). We are presenting the municipal map primarily because Slovenia's Spatial Planning Act (Zakon, 2007) requires that hazard maps for various natural hazards be included in municipal spatial plans and, as such, they are therefore a basic spatial-planning document (Komac and Zorn, 2010b, 107). As geographers, we have already created such municipal maps for a number of Slovenian municipalities; for example, for Brda (Ažman Momirski et al., 2008), Jezersko (Klabus et al., 2009), and Tržič (Natek et al., 2010).

As already stated, to create these maps we used the certainty factor method, which was first used by Shortliffe and Buchanan (1975) and later on by Heckerman (1986). To model landslide hazard, it was used, for example, by Binaghi et al. (1998).

Map production generally uses geographical information systems, and takes into account various contributing factors and various methods of calculating the significance of contributing factors for land-sliding. These are used to solve the problem of comparing or combining various data layers. The data differ in terms of their presentation method, they can be vector- or raster-based, and they are often not homogenous because they have been collected by various people or institutions that followed the rules or methods selected to varying extents. This can significantly reduce the model's accuracy. 


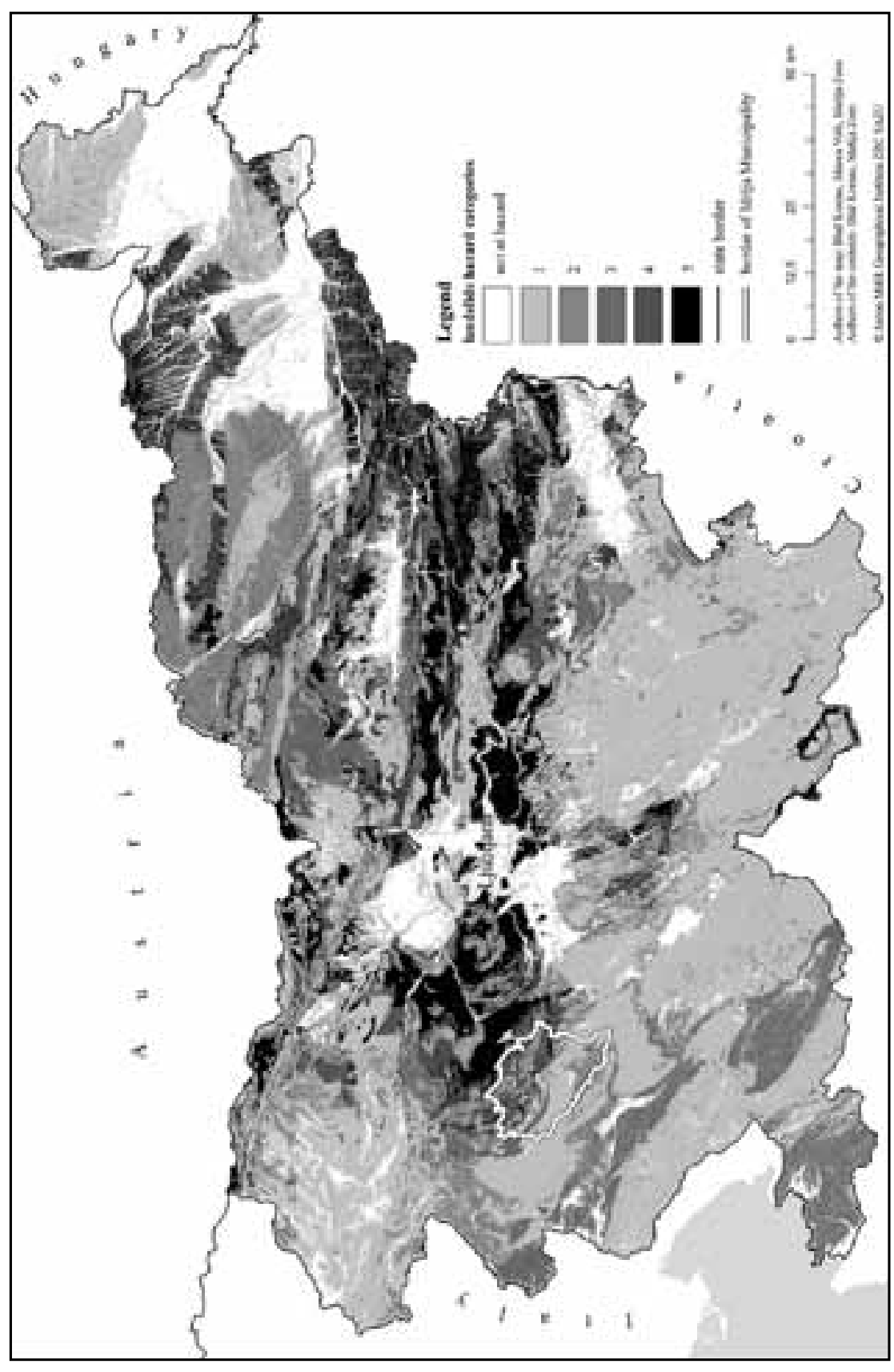

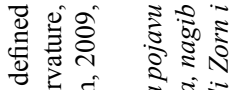

ช

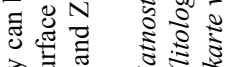

可 की

윰 $\frac{1}{3}$ क ज :

च.

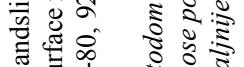

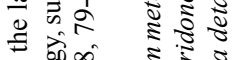

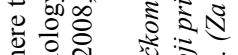

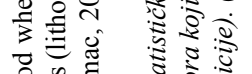

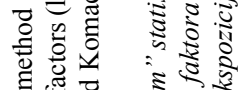

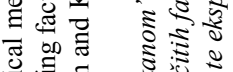

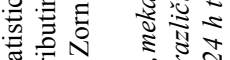

का

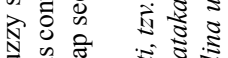

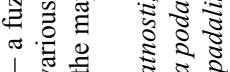

उ

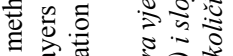

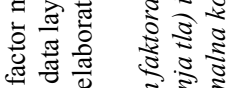

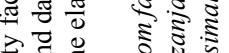

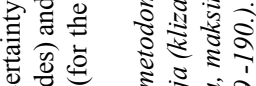

记

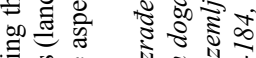

पू山

ठ ठ

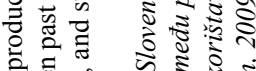

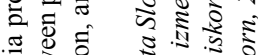

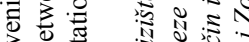

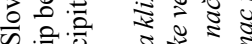

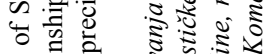

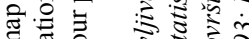

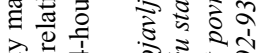

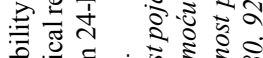

芫.

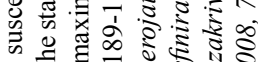

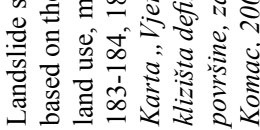

官宁 
In producing landslide susceptibility maps for Slovenia, several contributing factors were taken into account: lithology, surface inclination, surface curvature, land use, maximum 24-hour precipitation, and surface aspect (Zorn and Komac, 2008). Data on actual landslide occurrences were also added from the National Landslide Database (Nacionalna, 2006). This database was established in mid-2005. It contains information about 6,602 mass movements, of which 3,257 were precisely spatially located. The polygon vector data include information about relative location (to roads, buildings) and absolute location (Gauss-Krüger coordinates), information about the width, length, and depth of landslides, and information about their activity. It also includes information about sources of information and damage caused by landslides.

On average, the landslide hazard is the greatest in the Slovenian alpine regions, where the areas most susceptible to landslides (hazard categories 4 and 5) cover more than $20 \%$ of the entire area. In the Pannonian regions, landslide-prone areas cover around $10 \%$ of the area and around $8 \%$ in Mediterranean regions. The areas least threatened by landslides are the (predominantly) limestone Dinaric regions, where the areas most susceptible to landslides represent around 7\% of the area (Zorn and Komac, 2008; Komac and Zorn, 2009).

\section{CONCLUSION}

"Geographers have a major role to play in landslide hazard and risk assessment. This is because, like all hazards, the risk results from the interrelationship between the human and physical environments-a traditional focus of geographical study" (Crozier, 1999, 92).

If it is possible anywhere within geography, then it is possible in the geography of natural hazards to agree with the statement by Pacione $(1999,16)$ that "applied geographers have made a major contribution to the resolution of real-world problems." According to Montz and Tobin $(2011,1)$ "the tradition of applying geographical knowledge, techniques, and skills to the complexity of issues associated with natural hazard and disasters" began after the publication of the work Human Adjustment to Floods (White, 1945) more than six and a half decades ago.

Despite their wealth of knowledge, geographers and geomorphologists have all too often been neglected by decision-making bodies. The International Association of Geomorphologists is also aware of the insufficient attention paid to geomorphologists' knowledge when studying and preventing natural hazards, and this association adopted a declaration on the matter in 2005 (Declaration, 2005). It states that "geomorphological research that produces maps and models identifying areas susceptible to damage should always be part of the scientific basis of decision-making to reduce susceptibility and prevent loss of life and property by natural events," and that "geomorphologists should contribute to decision-making, at all levels, to prevent and mitigate geomorphological hazards and to encourage decision makers to place higher priority on prevention and mitigation of risks associated with natural hazards." Goudie $(2004,28)$ writes that "a major new stimulus to applied geomorphological research has been a concern with global environmental change and the potential consequences of global warming." 


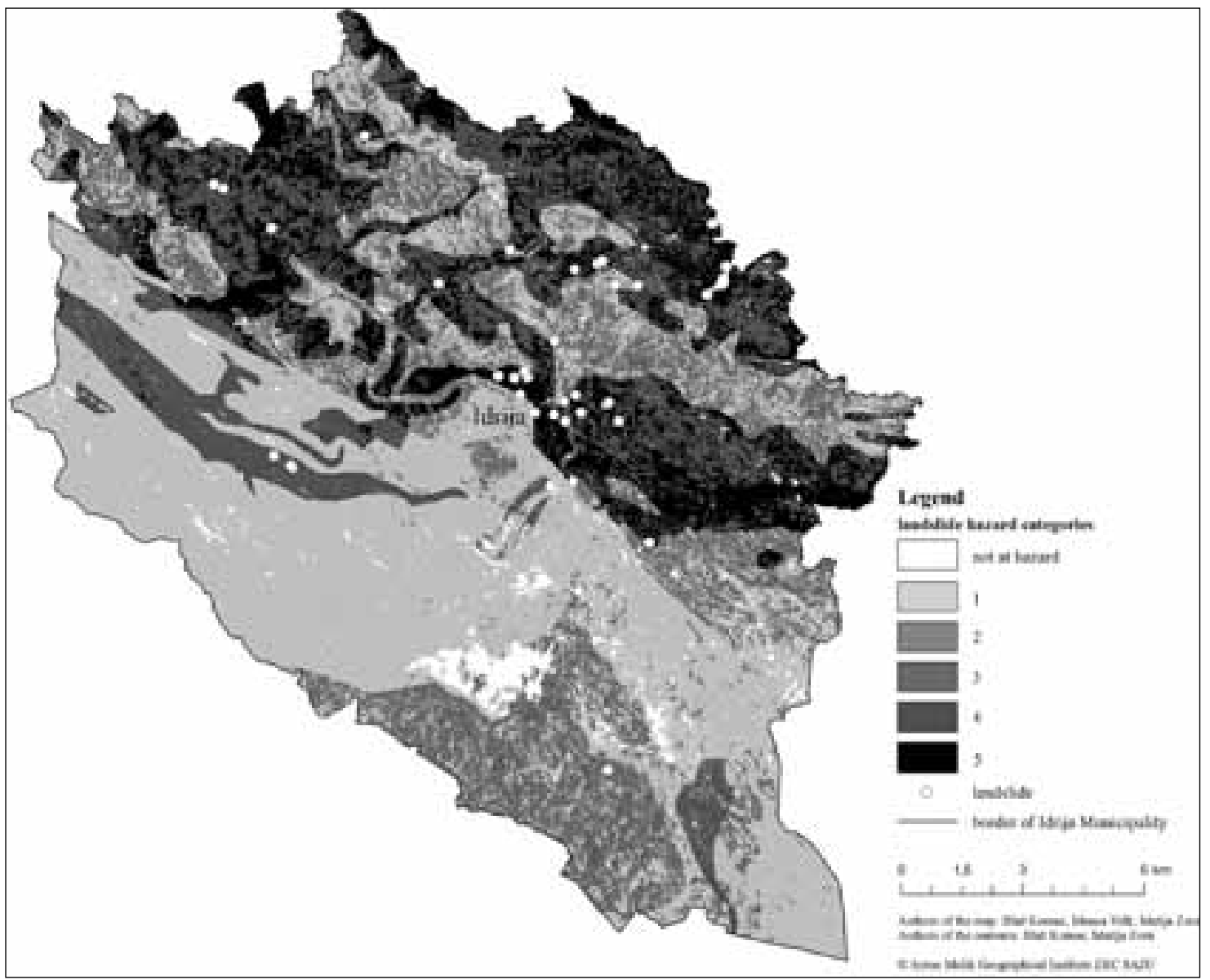

Fig. 5 Landslide susceptibility map of the Municipality of Idrija (western Slovenia) produced using the certainty factor method (Komac and Zorn, 2010b, 101). This map was created as one of the expert bases for preparing the innovative strategy for the sustainable development of the Municipality of Idrija (Nared et al., 2010) and serves as an example of the application of geomorphological knowledge to landslides hazards assessment at the municipal level.

Sl. 5. Karta ,Vjerojatnost pojavljivanja klizišta” za općinu Idrija (zapadna Slovenija), izrađena metodom faktora vjerojatnosti (Komac i Zorn, 2010b, 101). Karta je napravljena kao stručni doprinos pri izradi inovativne strategije održivog razvoja općine Idrija (Nared i sur., 2010) i primjer je primjene geomorfoloških znanja u procjeni rizika od klizišta na općinskoj razini.

The damage caused by landslides has been increasing in recent decades. In some places, this is truly the result of greater frequency or intensity of natural processes; however, this can largely be ascribed to human encroachment into previously unsettled areas that are threatened by natural processes. Despite the constant threat, there is an extremely low level of awareness regarding this issue in society. It is thus alarming to find that, in Slovenia, relief and geomorphic processes, including landslides, are not taken into account in landuse planning (Komac et al., 2008). 
Traditional settlement should serve as a good example. In the past, people usually only built in areas that were not threatened by geomorphic processes. Another step forward could be achieved by planning settlements in and directing them to safe areas, and protecting existing settlements with appropriate measures if possible and as needed (Komac and Zorn, 2009; 2010a).

Landslide susceptibility maps provide a quick and effective way to determine the areas that people should not exploit or for which we know that any development would demand special construction and other measures.

In Slovenia, national funds are primarily used for clean-up, and less so for prevention. It would certainly be good if a greater portion of these funds could be earmarked for prevention; the funds that were used from 2002 to 2005 alone to clean up six major landslides would, in theory, have been sufficient to produce quality landslide-risk maps for all of Slovenian's municipalities (Komac and Zorn, 2005, 92). From 1994 to 2008, damage due to landslides and avalanches amounted to $0.033 \%$ of the GDP, or nearly $8 \%$ of the annual damage due to natural disasters (Zorn and Komac, 2011a; 2011b). With regard to the damage due to natural disasters in Slovenia, landslides and avalanches ranked fifth (from 1994 to 2008), behind drought (nearly $26 \%$ of average annual loss due to natural disasters), hail (just over 20\%), flooding (nearly 19\%), and strong winds (just over 12\%)

\section{REFERENCES}

Alexander, D., 1991: Applied geomorphology and the impact of natural hazards on the built environment, Natural Hazards 4, 57-80.

Ardizzone, F., Cardinali, M., Carrara, A., Guzzetti, F., Reichenbach, P., 2002: Impact of mapping errors on the reliability of landslide hazard maps, Natural hazards and earth system sciences 2 (1-2), 3-14.

Ažman Momirski, L., Kladnik, D., Komac, B., Petek, F., Repolusk, P., Zorn, M., 2008: Terasirana pokrajina Goriških brd, Geografija Slovenije 17, Založba ZRC, Ljubljana.

Binaghi, E., Luzi, L., Madella, P., Pergalani, F., Rampini, A., 1998: Slope instability zonation: A comparison between certainty factor and fuzzy Dempster-Shafer approaches, Natural hazards 17 (1), 77-97.

Cendero, A., Dramis, F., 1996: The contribution of landslides to landscape evolution in Europe, Geomorphology $15(3-4), 191-211$.

Ciglič, R., Zorn, M., Komac, B., 2010: Ugotavljanje plazovitosti z metodo odločitvenih dreves. in: Geografski informacijski sistemi v Sloveniji 2009-2010 (eds. Drago, P., Zorn, M.), Založba ZRC, Ljubljana, 111-120.

Coates, D. R., 1984: Geomorphology and public policy. in: Developments and Applications of Geomorphology (eds. Costa, J. E., Fleisher, P. J.), Springer, New York, 97-132.

Crozier, M. J., 2010: Landslide geomorphology: An argument for recognition, with examples from New Zealand, Geomorphology 120 (1-2), 3-15.

Crozier, M., 1999: Landslides. in: Applied Geography: Principles and Practice (ed. Pacione, M.), Routledge, London, 83-94.

Declaration, International Association of Geomorphologists, Zaragoza, 2005. http://www.geomorph.org/sp/ arch/es05/Declaration2005.pdf (20. 12. 2010). 
Glade, T., 2005: Linking debris-flow hazard assessments with geomorphology, Geomorphology 66(1-4), 189-213.

Glade, T., Crozier, M. J. (eds.), 2010: Landslide geomorphology in a changing environment, Geomorphology $120(1-2), 1-90$.

Goudie, A. S, 2004: Applied geomorphology. in: Encyclopedia of Geomorphology, Volume 1 (ed. Goudie, A. S.), Routledge, London, 28-31.

Heckerman, D. E., 1986: Probabilistic interpretation of MYCIN's certainty factors. in: Readings in uncertain reasoning (eds. Shafer, G., Pearl, J.), Morgan Kaufmann Publishers Inc., San Francisco, 298-312.

Klabus, A., Pavšek, M., Zorn, M., Komac, B., 2009: Poplavna, erozijska, plazovita in plazljiva območja na teritoriju občine Jezersko, VGP Projekt d.o.o, Kranj.

Komac, B., Natek, K., Zorn, M., 2008: Geografski vidiki poplav v Sloveniji, Geografija Slovenije 20, ZRC Publishing, Ljubljana.

Komac, B., Zorn, M., 2005: Geomorfološke nesreče in trajnostni razvoj, IB revija 39 (4), 87-97.

Komac, B., Zorn, M., 2009: Statistical landslide susceptibility modeling on a national scale: the example of Slovenia, Revue roumaine de géographie 53 (2), 179-195.

Komac, B., Zorn, M., 2010a: Statistično modeliranje plazovitosti v državnem merilu. in: Od razumevanja do upravljanja, Naravne nesreče 1 (eds. Zorn, M., Komac, B., Pavšek, M., Pagon, P.), Založba ZRC, Ljubljana, 65-74.

Komac, B., Zorn, M., 2010b: Plazovitost v občini Idrija. in: Na prelomnici: razvojna vprašanja občine Idrija (eds. Nared, J., Perko, D.), Založba ZRC, Ljubljana, 97-109.

Montz, B. E., Tobin, G. A., 2011: Natural hazards: An evolving tradition in applied geography, Applied Geography 31 (1), 1-4.

Nacionalna podatkovna baza zemeljskih plazov, Uprava Republike Slovenije za zaščito in reševanje Ministrstva za obrambo Republike Slovenije, Ljubljana, 2006.

Nared, J., Smrekar, A., Bole, D., Kozina, J., Fridl, J., Polajnar Horvat, K., Gabrovec, M., Repolusk, P., Zavodnik Lamovšek, A., Kavaš, D., Gantar, D., Koman, K., 2010: Strokovno gradivo za pripravo inovativne strategije trajnostnega razvoja Občine Idrija, Geografski inštitut Antona Melika ZRC SAZU, Ljubljana.

Natek, K., Krevs, M., Lampič, B., Mrak, I., Ogrin, D., Repe, B., Stepišnik, U., 2010: Karte erozijske in poplavne nevarnosti, plazljivosti in nevarnosti snežnih plazov za območje občine Tržič, Oddelek za geografijo Filozofske fakultete, Ljubljana.

Pacione, M., 1999: In pursuit of useful knowledge: the principles and practice of applied geography. in: Applied Geography: Principles and Practice (ed. Pacione, M.), Routledge, London, 3-18.

Shorthliffe, E. H., Buchanan, G. G., 1975: A model of inexact reasoning in medicine, Mathematical biosciences 23, 351-379.

Westen, v. C. J., Seijmonsbergen, A. C., Mantovani, F., 1999: Comparing landslide hazard maps, Natural hazards $20(2-3), 137-158$.

White, G. F., 1945: Human adjustments to floods: A geographical approach to the flood problem in the United States, Research Paper No. 29, University of Chicago press, Chicago.

Zakon o urejanju prostora, Uradni list Republike Slovenije 33/2007, Ljubljana.

Zorn, M., Komac, B., 2006: Geomorfologija in prostorsko planiranje, Urbani izziv 17 (1-2), 66-72.

Zorn, M., Komac, B., 2008: Zemeljski plazovi v Sloveniji, Georitem, 8, ZRC Publishing, Ljubljana.

Zorn, M., Komac, B., 2009: The importance of landsliding in a flysch geomorphic system: the example of the Goriška brda Hills (W Slovenia), Zeitschrift für Geomorphology N. F. suppl. 53 (2), 57-78.

Zorn, M., Komac, B., 2011a: Naravne nesreče v Sloveniji, Idrijski razgledi 56 (1), 16-25. 
Zorn, M., Komac, B., 2011b: Damage caused by natural disasters in Slovenia and globally between 1995 and 2010, Acta geographica Slovenica 51 (1), 7-41.

Received (Primljeno): 2011 - 01 - 15

Accepted (Prihvaćeno): 2011 - 12 - 30

\section{Matija Zorn}

Anton Melik Geographical Institute

Scientific Research Centre of the Slovenian

Academy of Sciences and Arts

Gosposka ulica 13

SI - 1000 Ljubljana

matija.zorn@zrc-sazu.si

\section{Blaž Komac}

Anton Melik Geographical Institute

Scientific Research Centre of the Slovenian

Academy of Sciences and Arts

Gosposka ulica 13

SI - 1000 Ljubljana

blaz.komac@zrc-sazu.si 
